\title{
MEWUJUDKAN DIGITALPRENEUR DALAM ERA REVOLUSI INDUSTRI 4.0 PADA TWT LEARNING CENTRE
}

\author{
${ }^{1 *}$ Suyatin, ${ }^{2}$ Retno Japanis Permatasari, ${ }^{3}$ Panji Galih Kusumo Adie, \\ ${ }^{4}$ Rachmawaty, ${ }^{5}$ Eko Cahyadi \\ Universitas Pamulang, Tangerang Selatan, Banten, Indonesia \\ Email : $\underline{\text { dosen0142@unpam.ac.id }}$
}

Manuskrip: Desember -2021; Ditinjau: Januari -2022; Diterima: Januari -2022; Online: Januari-2022; Diterbitkan: Januari-2022

\begin{abstract}
ABSTRAK
Sebelum era revolusi industry 4.0 pola usaha yang mendominasi adalah bisnis atau usaha yang efisien dan produktif, maka di era revolusi industry 4.0 dan era digital, pola bisnis atau usahanya berubah menjadi inovatif dan kreatif. TWT Learning Centre sebagai lembaga pelatihan konsultasi bisnis dan pendidikan, diharapkan mampu memberikan dan mentransfer ilmu tentang digitalprenenur dan memotivasi para mahasiswa dan para pelaku bisnis muda untuk segera beradaptasi dan dunia digital yang sangat dinamis. Melakukan adaptasi dengan dunia digital melakukan pemasaran melalui Online atau e-commerce yang dapat meningkatkan daya jual produk dan bersaing dengan usaha sejenis lainnya. Permasalahan yang ada pada mitra yaitu kurangnya pelatihan yang memberikan tentang digipreneur dan meningkatkan motivasi untuk menjadi kreatif bagi para pelaku bisnis solusi yang diusulkan atau ditawarkan dalam kegiatan PKM ini adalah (1) Pemberian motivasi, ilmu digipreneur dan motivasi kisah sukses dalam berwirausaha. (2) Bimbingan dalam menjalankan bisnis. Bimbingan cara memasarkan produk secara online. target luaran yang diharapkan yaitu (1) Jurnal PKM (Pengbadian Kepada Masyarakat) yang di dalamnya terdapat sebuah wawasan digipreneur yang dapat diambil pelajarannya, (2)Konsultasi dan Bimbingan oleh Tim Dosen Unpam, kepada wirausaha pemula yang terdiri dari pelajar dan mahasiswa sampai wirausaha pemula yang terdiri dari pelajar dan mahasiswa benar-benar dapat mengembangkan usahanya.
\end{abstract}

\section{Kata Kunci: Digipreneur, Kreatif, TWT Learning Centre, Pebisnis Muda}

\section{PENDAHULUAN}

Belakangan ini kata Industry 4.0 sering digemakan oleh banyak orang. Akan tetapi, hingga saat ini masih banyak masyarakat yang masih belum mengerti apa itu Industry 4.0 dan bagaimana hal tersebut akan memberikan sumbangsih terhadap kemajuan Indonesia. Istilah Industry 4.0 pertama kali digemakan pada Hannover Fair, 4-8 April 2011. Istilah ini digunakan oleh pemerintah Jerman untuk memajukan bidang industri ke tingkat selanjutnya, dengan bantuan teknologi. Mengutip dari laman Forbes, revolusi industri generasi keempat bisa diartikan 
sebagai adanya ikut campur sebuah sistem cerdas dan otomasi dalam industri. Hal ini digerakkan oleh data melalui teknologi machine learning dan AI. Jiwa-jiwa muda yang memiliki bisnis atau UMKM (Usaha Mikro Kecil Menengah) harus terus berinovasi dan mengembangkan bisnisnya agar terus dapat berkembang dan mampu bertahan walaupun di masa pandemi saat ini. Salah satu mempertahankannya dapat dilakukan melalui strategi pemasaran secara Online atau disebut juga digiprenenur, seperti pemanfaatan media sosial di kalangan mudamudi agar membuka peluang terjualnya produk atau jasa yang dipasarkan menjadi lebih luas dan terencana.

Dengan adanya TWT Learning Centre sebagai lembaga pelatihan konsultasi bisnis dan pendidikan, diharapkan mampu memberikan dan mentransfer ilmu tentang digitalprenenur dan memotivasi para mahasiswa dan para pelaku bisnis muda untuk segera beradaptasi dengan dunia ecommerce dan dunia digital yang sangat dinamis. Melakukan adaptasi dengan dunia digital melakukan pemasaran melalui Online atau e-commerce yang dapat meningkatkan daya jual produk dan bersaing dengan usaha sejenis lainnya. Hal ini menjadi sangat relevan dengan kebutuhan dunia bisnis yang terintegrasi dengan internet.

Survey yang dilakukan oleh Badan Pusat Statistik (BPS) dalam Fadly, H. D., \& Sutama, S. (2020), mendata "Pengguna e-commerce yaitu sejumlah 3.504 kepala keluarga (KK) pada 101 daerah di seluruh provinsi yang terdapat di Indonesia. Dari data tersebut dapat diambil kesimpulan bahwa hanya sekitar $15,08 \%$ dari keseluruhan yang menggunakan usaha e-commerce, hal ini berbading terbalik dengan yang tidak menggunakan usaha e-commerce yaitu sebanyak 84.92\%." Seperti diagram terlampir di bawah ini.

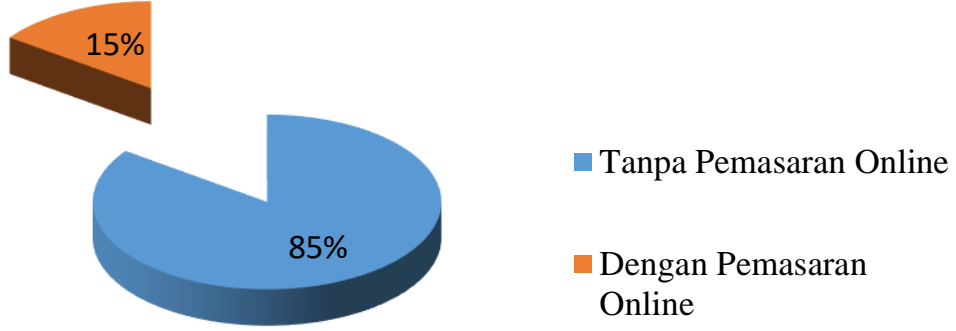

Gambar 1. Presentase Pemasaran Online/e-commerce, tahun 2020

Dengan melihat data di atas, sebuah usaha yang menjual produk atau jasanya melalui e-commerce di indonesia masih tergolong sangat rendah, hal ini juga mencerminkan wilayah Tangerang masih jauh dari harapan usahanya untuk dapat memasarkannya secara Online, para pelaku usaha lebih memilih menjual produk dan atau jasanya melaluinya toko atau membuka lapak di pinggir jalan, padahal pada era kompetitif ini terutama saat pandemi covid-19 seperti ini, perlu adanya pemasaran melalui Online atau e-commerce yang dapat meningkatkan daya jual produk dan bersaing dengan usaha sejenis lainnya.

Yang sangat menarik dari semua ini adalah meningkatnya pemain-pemain baru (new commers) dalam bisnis kreatif seperti 4 bidang yang dominan, yaitu 
bidang : kuliner, fashion, Kriya dan aplikasi multimedia (sumber : bekraf 2015), yang diisi oleh pelaku-plekau bisnia anak-anak usia produktif yang kreatif . hal ini terjadi karena mudahnya akses dan transfer knowledge dengan menggunakan fasilitas search engine (google) dan lainnya. Menurut data becraft tahun 2018, bahwa sumbangsih bisnis creative ini telah menyumbang Kontribusi bisnis ekonomi kreatif (Bekraf) lebih dari 1000 Triliun (sumber kompas.com 25 september 2018) dengan pelaku bisnis dominan dilakukan antara umur 25-59 sebesar $75.4 \%$. artinya saat ini semua orang bisa melakukan bisnis, tanpa harus memiliki modal dan asset besar, seseorang yang memiliki ide creative dengan mudah dapat ditemukan oleh kelompok orang yang memiliki asset modal pertemuan mereka dilakukan di dunia maya dengan cepat dan praktis, kuncinya adalah kreativ dan inovatif. Era industri 4.0 ditandai konektivitas dan interaksi melalui teknologi informasi dan komunikasi yang terintegrasi. Konektivitas dan digitalisasi itu membuat nilai rantai manufaktur lebih efisien dan kualitas produknya (Reza, T. S., \& Hermawansyah, W. 2019)

Karena saat ini pada masa era digital, maka sebuah solusi dalam mengembangkan usaha yaitu dengan pemasaran melalui digital atau promosi Online, hal ini sebagaimana riset yang dilakukan oleh Effendy, A. A., \& Sunarsi, D. (2020). "Promosi Online lebih efektif pemasarannya melalui Media Sosial yaitu Whatsapp dengan presentase paling tinggi sebesar 34\%, Instagram dengan presentase $31 \%$, facebook dengan presentase $19 \%$ dan selainnya, informan juga menggunakan media sosial berupa twitter sebesar $4 \%$, website sebesar $4 \%$ dan Online shop: shopee sebesar 8\%, sehingga promosi sangat efektif dilakukan melalui media Online terutama lebih efektif dilakukan promosinya melalui media sosial dibandingkan promosi melalui media elektronik, dan media cetak."

Hal ini sesuai dengan tulisan dalam berita online oleh Mahnun Mas'adi. (2020), "Dengan semakin majunya tehnologi, dan perubahan perilaku konsumtif masyarakat Indonesia, dikarenakan dampak Covid 19, maka E-commerce semakin memegang peranan penting dalam perubahan perilaku konsumen tersebut. Berikut komentar para CEO E-commerce terkenal di Indonesia; CEO blibli.com; "sebelum covid-19, e-commerce hanyalah sebuah pilihan. Namun untuk sekarang, penting sekali bagi toko retail dan produsen untuk menjual produk melalui platform ecommerce agar mampu mempertahankan bisnis mereka. hal ini akan memberikan dampak jangka panjang yang positif karena konsumen akan semakin terbiasa berbelanja secara online". Lalu ada juga CEO go-jek; "pasar pengiriman makanan di indonesia berpotensi meningkat dua kali lipat pada tahun 2020 akibat dari wabah covid-19".

Oleh karena itu, TWT Learning Centre sebagai lembaga pelatihan konsultan bisnis dan pendidikan perlu lebih mendalami mengenai digipreneur, agar usaha atau bisnis yang dijalankan dapat mampu bertahan dan berkembang di saat pandemi seperti saat ini. Selain itu keilmuan para peserta nantinya juga akan bertambah dalam dunia digipreneur.

Dalam pengabdian kepada masyarakat (PKM) yang dilakukan oleh dosendosen UNPAM khsusnya dosen Manajemen Fakultas Ekonomi, merupakan salah 
satu upaya dalam berpartisipasi dan menjalankan peran untuk membekali dan memberikan ilmu pengetahuan, keterampilan dan karakter dalam tugasnya memberikan transfer ilmu pada TWT Learning Centre dengan tema, "Mewujudkan Digitalprenenur Dalam Era Revolusi Industri 4.0 Pada TWT Learning Centre ".

\section{METODE PELAKSANAAN KEGIATAN}

Metode Pelaksanaan Pengabdian Masyarakat ini di antaranya : Tahap Pertama yaitu: saat permulaan dalam pelaksanaa kegiatan, dimulai dengan ice breaking dan brain gym agar peserta PKM dapat lebih termotivasi mengikuti penyuluhan yang diberikan oleh dosen-dosen Fakultas Ekonomi Universitas Pamulang. Sambutan sebagai pembuka dari rangkaian acara oleh Ketua Pelaksana PKM dosen Fakultas Ekonomi Universitas Pamulang dan dari pihak wirausaha pemula yang terdiri dari pelajar dan mahasiswa yaitu Founder TWT Learning Centre Pusat serta dilanjutkan dengan pembacaan doa sebelum memulai kegiatan agar seluruh rangkaian kegiatan dapat berjalan lancar. Penyajian materi kegiatan Pemberian Materi PKM dengan tema "Mewujudkan Digitalprenenur Dalam Era Revolusi Industri 4.0 TWT Learning Centre". Adapun Prof. Dr. S. Nasution (2015:26) berpendapat mengenai "Ciri-ciri Belajar yang ditinjau berdasarkan sumber yaitu diantaranya memanfaatkan sepenuhnya segala sumber informasi sebagai sumber bagi pelajaran termasuk alat-alat audio-visual dan memberi kesempatan untuk merencanakan kegiatan belajar dengan mempertimbangkan sumber-sumber yang tersedia." Dalam pemberian materi kewirausahaan menggunakan video conference berupa Aplikasi Zoom. Setelah Pemberian pelatihan mengenai kewirausahaan kemudian dilanjutkan dengan kuis dan tanya jawab.Rangkaian kegiatan diakhiri dengan pembacaan doa penutup

Dalam pemberian materi oleh dosen-dosen menggunakan alat bantu berupa zoom dikarenakan masih dalam masa pandemic Covid 19 agar peserta lebih fokus dalam mengikuti penyuluhan seperti gambar di bawah ini:

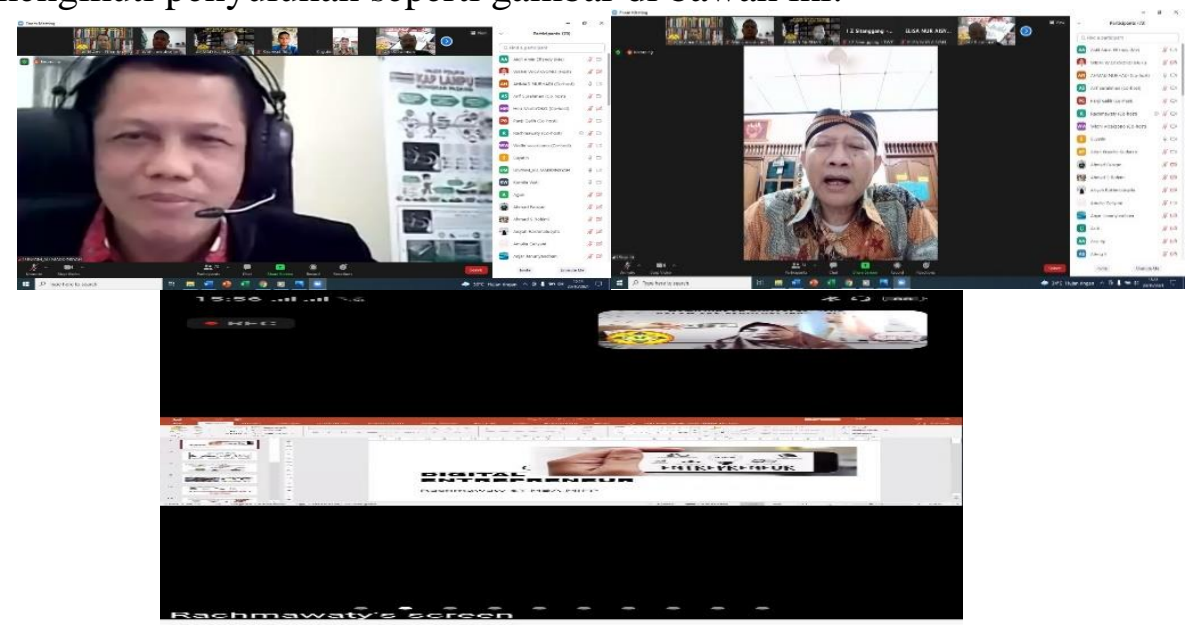

Gambar 2. Tim PKM Dosen Universitas Pamulang sedang memberikan materi

Kegiatan diadakan pada TWT Learning Centre selama 3 hari yaitu pada tanggal 23, 24 dan 25 Oktober 2021. 


\section{HASIL DAN PEMBAHASAN}

Hasil dari pemberian materi wawasan wirausaha yang kreatif, inovatif dan diferensiatif oleh dosen Manajemen Universitas Pamulang dan simulasi dan pendampingan bagi mitra TWT Learning Centre untuk akses digital dalam pemasaran dengan harapan bisa memajukan usahanya sampai berkembang.

Permasalahan yang dihadapi oleh para pengusaha TWT Learning Centre ialah Kurangnya Ilmu pengetahuan dalam TWT Learning Centre belum memiliki ilmu pengetahuan dan wawasan yang memadai mengenai wirausaha yang kreatif, inovatif dan diferensiatif dan Tidak adanya akses dalam dunia digital dalam pengembangan usahanya.

Dari serangkaian kegiatan pengabdian Tim PKM Dosen dan mahasiswa Fakultas Ekonomi jurusan Manajemen Universitas Pamulang, maka hasil dari kegiatan pengabdian yang dilakukan adalah sebagai berikut: Pemahaman mengenai ilmu kewirausahaan yang kreatif, inovatif dan diferensiatif TWT Learning Centre dapat memahami ilmu kewirausahaan yang kreatif, inovatif dan diferensiatif serta dapat mengambil pelajaran dari kisah sukses beberapa orang yang sukses dalam berwirausaha..

Setelah pemberian motivasi dan ilmu kewirausahaan kepada TWT Learning Centre, tim PKM dari dosen-dosen Unpam membimbing TWT Learning Centredalam simulasi dagang dan cara menjual produk dan kemudian kita membimbing sampai TWT Learning Centre benar-benar dapat memulai dan menjalankan usahanya. Bahkan tim dosen-dosen Unpam akan bersedia membuka konsultasi bagi para remaja yang kesulitan saat nmenjalankan usahanya. Konsultasi ini diberikan agar pihak mitra yaitu TWT Learning Centre lebih termotivasi dan merasa optimis jika mereka merasa kesulitan dan merasa bingung dalam memulai usaha dan menjalankan usaha sampai memperoleh laba maksimal dan mengembangkan usahanya.

Pendampingan bagi mitra untuk akses internet dalam dunia digital. Pihak Mitra yaitu TWT Learning Centre diberikan pendampingan agar mereka dapat mengetahui cara dalam menggunakan intenet maupun dunia digital dalam menjalankan usahanya, dengan harapan bisa memajukan usahanya sampai berkembang.

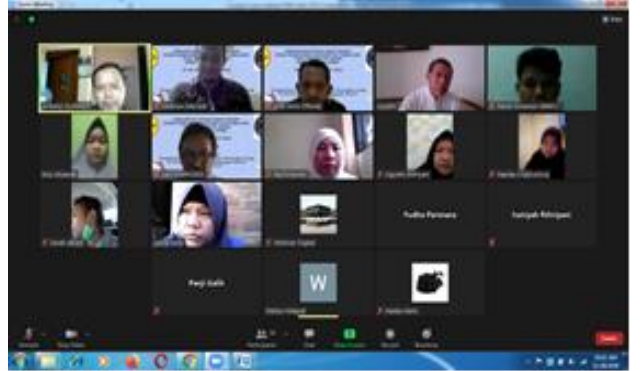

Gambar 3 Pembukaan oleh Tim PKM

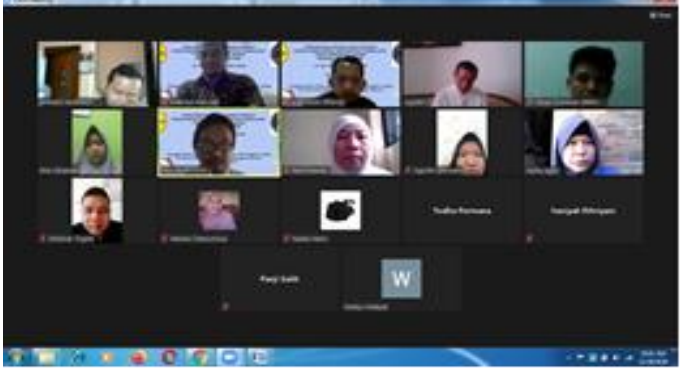

Gambar 4. Pemberian Materi PKM

Kegiatan pada gambar di atas pembukaan dan doa agar seluruh rangkaian kegiatan PKM dapat berjalan lancar, yang dilanjutkan dengan mengadakan ice breaking sebelum pemberian materi keuangan agar peserta lebih fokus dalam 
mengikuti penyuluhan yang dilakukan dosen-dosen Fakultas Ekonomi Universitas Pamulang.

\section{KESIMPULAN}

Hasil dari Pelaksanaan kegiatan PKM oleh dosen-dosen Fakultas Ekonomi Universitas Pamulang dapat membuahkan hasil yang positif terlihat dari antusias dan bersemangat dalam mengikuti pemberian materi, tanya jawab dan kuis.

Saran kami bagi TWT Learning Centre untuk dapat bertambahnya keilmuan pelaku TWT Learning Centre dalam menjadikan usahanya lebih kreatif, inovatif dan diferensiatif, dan mendapatkan akses dalam dunia digitalpreneur Kami berharap kegiatan pengabdian kepada masyarakat di masa yang akan datang dapat lebih terprogram dan terlaksana dengan baik. Semoga kegiatan pengabdian masyarakat ini dapat bermanfaat bagi masyarakat, khususnya TWT Learning Centre. masyarakat ini dapat bermanfaat bagi masyarakat, khususnya Komunitas XBank Tangerang.

\section{DAFTAR PUSTAKA}

Budiyanto, A., \& Effendy, A. A. (2020). Analisa Kebijakan Pemerintah Kota Tangerang Selatan terhadap Pemberdayaan Koperasi dan UMKM dan Dampaknya terhadap Pemerataan Kesejahteraan Masyarakat. Jurnal Mandiri: Ilmu Pengetahuan, Seni, Dan Teknologi, 4(1), 80-93.

Djamarah, Syaiful Bahri dan Aswan Zain. 2014. Strategi Belajar Mengaja. Cet 5, PT Rineka Cipta, Jakarta. Hlm. 39-41

Effendy, A. A., Budiyanto, A., Nurhadi, A., Murtiyoko, H., \& Mas'adi, M. (2020). "Implementasi Kewirausahaan dan Koperasi di Sekolah pada SMK Mulia Buana, Parung Panjang-Kab. Bogor.” DEDIKASI PKM, 1(2), 105-110.

Effendy, A. A., \& Sunarsi, D. (2020). Persepsi Mahasiswa Terhadap Kemampuan

Dalam Mendirikan UMKM Dan Efektivitas Promosi Melalui Online Di Kota Tangerang Selatan. Jurnal Ilmiah MEA (Manajemen, Ekonomi, \& Akuntansi), 4(3), 702-714.

Erlangga, H. (2021). Effect Of Digital Marketing And Social Media On Purchase Intention Of Smes Food Products. Turkish Journal of Computer and Mathematics Education (TURCOMAT), 12(3), 3672-3678.

Fadly, H. D., \& Sutama, S. (2020). "Membangun Pemasaran Online Dan Digital Branding Ditengah Pandemi Covid-19." Jurnal Ecoment Global: Kajian Bisnis dan Manajemen, 5(2), 213-222.

Haryadi, R. N., Anda Rojali, Khumidin, \& M. Fauzan. (2021). Sosialisasi Penggunaan Online Shop berbasis Website di UMKM Cimanggis. Jurnal Pengabdian Masyarakat Madani (JPMM), 1(1), 10-16. https://doi.org/10.51805/jpmm.v1i1.3

Hamalik, Oemar. 2008. Kurikulum dan Pembelajaran, Cet. 7, PT. Bumi Aksara, Jakarta. Hlm. 37

http://mediakontroversi.co.id/2020/05/05/bunuh-virusnya-tapi-jangan-usahanya/ 
Mas'adi, M., Effendy, A. A., Nurhadi, A., Wicaksono, W., \& Murtiyoko, H. (2021). Berwirausaha Dengan Semangat Kolaborasi Bersama Kurir Online Pada Pelaku UMKM Di Wilayah Reni Jaya Pamulang Barat. Jurnal Pengabdian Dharma Laksana, 3(2), 173-178.

Nasution, Prof. Dr. S., 2015. "Berbagai Pendekatan dalam Proses Belajar dan Mengajar", PT Bumi Aksara, Jakarta

Rahayu, R., \& Day, J. (2015). Determinant Factors of E-commerce Adoption by SMEs in Developing Country: Evidence from Indonesia. Procedia-Social and Behavioral Sciences, 195, 142-150.

Reza, T. S., \& Hermawansyah, W. (2019). Masa Depan Bisnis Kreatif di Era Revolusi Industri 4.0 Ditinjau dari Kebijakan Sektor Publik, Bisnis dan Perpajakan. Majalah Ilmiah Bijak, 16(1), 48-52.I.D.K.R., Brahmayanti, L.A. dan Subaedi. 2010. "Kompetensi SDM UKM dan Pengaruhnya Terhadap Kinerja UKM di Surabaya.” Jurnal Manajemen dan Kewirausahaan, 12 (1). 